\title{
ARTE DE MUERTE Y VIDA
}

\section{Diego Irarrazaval}

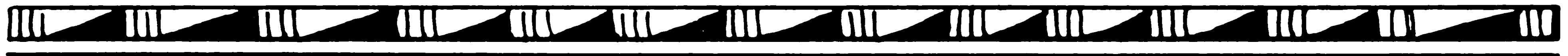

LA SENSIBLDAD ARTISTICA de la población andina señala su porvenir y el de la humanidad. Ante la mundialización de algunos comportamientos humanos (y la exclusión de otros), un pueblo ejerce su libertad al ser como es $y$, por consiguiente, al ser diferente. Esta libertad ha caracterizado a las comunidades andinas.

Voy a detenerme en dos dimensiones: el arte cotidiano en torno a la muerte-vida y algunas elaboraciones en torno a la violencia-paz. Al examinar estos lenguajes nos preguntamos qué dicen sobre el porvenir no sólo de estos pueblos sino del conjunto de los seres humanos. Asuntos como la muerte-vida y la violenciapaz son universales. Al respecto preocupan algunos parámetros culturales mundializados: el paulatino vaciado de la vivencia de la muerte y la complicidad con el orden violento. En medio de todo esto, la población andina tiene un arte muy particular y genuinamente universal. (Esto mismo ocurre en otros terrenos: vínculos entre adultos y jóvenes, labor comercial y económica, migración y mestizaje, ritualidad religiosa y civil). Aquí me detengo en lo artístico. Es algo que siempre palpa- 


\section{DIEGO IRARRAZAVAL}

ba en mis indagaciones sobre la cultura y religión del pueblo, pero no sabía cómo encararlo. Ahora me atrevo a trazar unas líneas. No soy artista, ni estudioso de esta realidad. Admiro la belleza comunicada sobre todo por grupos atribulados y apasionados por vivir. Considero que las personas que cultivan el diálogo, la música, la oración contemplativa de esta tierra, y demás artes, son las más calificadas para hablar. Por mi parte solamente hago unas observaciones; las ofrezco a quienes producen $e$ interpretan su arte.

¿Qué es la estética andina? Esta pregunta nos conduce al silencio. Lo bello hace brillar los ojos, hace arder el corazón, y escasamente hace hablar. Pero se puede intentar decir algo, sin agobiar la experiencia a través de categorías conceptuales. La población andina tiene sus modos de sentir, expresar y recrear la realidad. Con su sensibilidad genera belleza. En estas regiones andinas la estética es comunicada por la gente común: artesanía, religión, elaboración de su vivienda y sus alimentos de fiesta, el juego, canto, danza, la socialización con ritos de armonía y de diferenciación. Y también es comunicada por especialistas: arte musical, artes plásticas, obras literarias, etc. Me parece, pues, incorrecto clasificar en un segundo lugar a la artesanía (como si fuera un producto de menor calidad) y poner en primer lugar el arte (realizado por élites). Me parece que vale todo lo que agrada, y comunica esa realidad indescriptible que es la belleza. También me parece inaceptable la marginación del arte andino a lo pasado y residual, y la exaltación de elementos modernos como más hermosos. Nos movemos pues en un terreno donde proliferan prejuicios y malentendidos. $Y$ ya que nos invade tanta basura del mercado mundial de la cultura, es necesario concentrar nuestra atención en la belleza que hace vivir plenamente.

Primero voy a delinear el contexto de la estética andina. Luego me detengo en el arte común, presente 
ARTE DE MUERTE Y VIDA

en ritos de la muerte. Paso a continuación a ver valores en canciones por la paz. Termino anotando lo que todo esto sugiere en cuanto al porvenir de estas regiones $y$ de otros seres humanos.

\section{Condicionamientos a la Estética}

En estas tierras andinas, las sensibilidades están marcadas por el colonialismo y la agresión moderna, y por la relativa autonomía y la gran capacidad creadora de vida. En estos contextos han madurado formas de arte. Lentamente como cualquier planta, han crecido y dado frutos. Poco a poco la población andina ha ido procesando tanto su desgarramiento y alineación como también su percepción de la verdad, lo bueno, lo bello. Son sentimientos hondos que llegan a plasmarse como arte. Esto no ocurre a una velocidad planificada, sino más bien según un ritmo pausado y ágil.

La población surandina suele ser evaluada, desde afuera y desde adentro, como gente desvalida $e$ incapaz. Esto se hace en comparación con otros estratos $y$ tipos de seres humanos que, supuestamente, tienen éxito y aportan más al desarrollo del país. Pues bien, en medio de este contexto discriminatorio, el arte andino tiene rasgos de integridad y de mediación, dos rasgos imprescindibles para encarar nuestros graves problemas y desafíos.

¿A qué se debe esa descalificación? Ella proviene de la sociedad envolvente y también de la poca auto-estima andina.

Por un lado tenemos poderosos factores externos:

a. El arte clásico y elitista que desdeña lo folklórico (como suele denominarse al arte popular).

b. La popularización de lo andino a costa de su incorporación en un mercado cultural que distorsiona su originalidad. 


\section{DIEGO IRARRAZAVAL}

c. Lo popular y lo andino son tildados como algo sensual $e$ inmoral (mientras que a las obras de las élites se les atribuye valor filosófico y espiritual).

d. La producción del pueblo suele ser catalogada como diversión, y no es vista como celebración que recrea la vida.

A estos factores se suman otros que provienen "de adentro", vale decir, descalificaciones hechas por el propio mundo andino. Anoto las que más me impresionan:

a. Una creciente opción -y no sólo de la juventud- por novedades de toda clase, favorecida por la publicidad capitalista y por el sueño del "progreso».

b. Una reproducción de costumbres propias -lo que es muy positivo- pero sin capacidad de competir con la industria cultural y sus grandes logros tecnológicos.

c. Por otra parte, bastante gente andina subordina su expresión artística a la obtención de prestigio ante sus semejantes y ante los pudientes de esta región.

d. Otro modo de auto-descalificación es estar más atento a (e identificarse con) modos en que lo andino es presentado por los medios de comunicación y no ver la inmensa creatividad al interior de la trayectoria andina. En resumen, existen considerables obstáculos, tanto ajenos como propios, para el desenvolvimiento de los talentos andinos.

Ahora bien, en medio de condiciones adversas ¿cómo expresa este pueblo mestizo $e$ indígena su sensibilidad? Entre sus muchas características, subrayo dos: una expresión integral y una modalidad mediadora.

El carácter integral del arte tiene como base el protagonismo de la comunidad. En vez de figuras individuales, aisladas, se trata de una producción compartida y de una comunicación convocadora. Un grupo de personas (parientes, colegas de trabajo o de una 
asociación juvenil, vecinos en un barrio, una comunidad rural) son portavoces del conjunto de la población, y en estos ambientes el arte representa $y$ enriquece $a$ todos. También es integral por la conjugación de expresiones. En este sentido resalta la danza: ella sintetiza el universo humano. En la danza hay expresión musical, movimiento espacial y coreografía teatral, arte textil (vestimentas $y$ adornos), ofrenda religiosa (danza en ocasión de fiestas de santos/as), la reciprocidad varónmujer, organización y planificación de actividades, identidad local y regional, canto, el arte del diálogo. En mayor o menor grado hay implicancias económicas (por ejemplo, danzas ligadas a lo agropecuario), a lo político (mecanismos de prestigio, crítica social en la coreografía de algunas danzas), a lo étnico (sensibilidades indígenas y mestizas). Es decir, están presentes los ejes de la simbología andina; la expresión artística no es una parcela ni una superestructura, más bien, expresa toda la condición humana.

Una segunda característica del arte es generar vínculos $e$ intermediaciones en medio de acontecimientos que disgregan y tensionan a la población andina. Anoto algunos rasgos. $\mathrm{El}$ arte reúne el rojo con el negro; a la luminosidad con la oscuridad en la existencia humana cósmica (lo que resalta en los textiles andinos). Interactúan sonidos agudos -como la quenacon golpes sonoros -como el bombo-. La tristeza tiene sus contrapuntos con el gozo (por ejemplo la presencia de bellos adornos en las imágenes dolorosas de Semana Santa). El cálculo se combina con la gratuidad (los 'cargos' o responsabilidades en las fiestas). El valor de cada individuo forma parte de la armonía en la comunidad (coreografía de la danza). Lo indígena se amalgama con lo mestizo (por ejemplo, las cruces con adornos mestizos y con frutos agrícolas). La tradición se encuentra con la modernidad (ritos antiguos y nuevos en la alimentación). En cada una de estas instancias 


\section{DIEGO IRARRAZAVAL}

artísticas hay distintos elementos que se conjugan 0 entran en contacto y mutua fecundación.

Este factor de 'intermediación' ha sido delicadamente descrito por Verónica Cereceda. Ella toma en cuenta varias realidades: mito, dibujo, juego, belleza del wayruro (una semilla roja y negra), textiles. Una de sus principales conclusiones es que la belleza es una experiencia sensible y una tarea a cumplir; es un "paso entre dos términos contrarios (enfermedad y salud, vida $y$ muerte, natural y sobrenatural, opaco y brillante, etc.)" Más adelante anota: «el contacto y la mediación no es todo contacto posible sino tan sólo aquel que, siendo difícil de lograr o siendo peligroso, requiere un

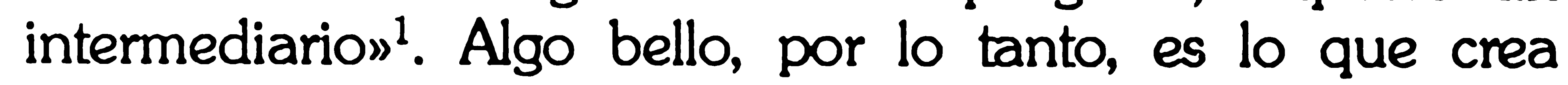
vínculos, conjuga, pone en contacto elementos distintos y discordantes. La belleza es armonía en el encuentro.

Esta calidad mediadora es evidente tanto en el arte como en la religión andina. Por eso, la fe de este pueblo se expresa con tantísima belleza y nos da un abrazo de paz profunda. A su vez, la producción artística está muy conectada con la vivencia de lo sagrado, del misterio, del festejo ritual. Sin embargo, las condiciones globales son adversas. En el caso de las condiciones en torno a la muerte, los parámetros actuales no la reconocen como una dimensión de vida. Más bien se intenta ocultarla y hacerla insignificante; la muerte es un hecho meramente biológico que no vale conmemorar ni menos aún festejar. Así no hay belleza en la muerte experimentada por el «mundo desarrollado". Qué contraste entre este desarrollo anti-muerte y la convivencia cálida con la muerte en los ámbitos andinos. Aquí es muy íntima la relación entre muerte

1 V. Cereceda, Aproximaciones a una estética andinax, en Tres reflexiones sobre el pensamiento andino, La Paz: HISBOL, 1987, pp. 217 - 219. 
y vida, $y$ esto se manifiesta artísticamente. En el caso del conflicto social (reflejado en los cantos que examinamos más adelante) el sentir dominante es controlar al pueblo para que cierre su corazón ante una realidad desgarrada. En contraposición a ello, brota un canto esperanzador que va más allá de dichos controles sobre la emoción popular. Gran parte de los cantos afirman el deseo de pasar desde la maldad hacia una vida digna y buena, acogedora y alegre. Esta 'intermediación' caracteriza al arte. Gracias a éste uno puede transitar simbólicamente entre términos contrarios.

\section{Belleza en la Muerte}

Según la sensibilidad andina, muerte $y$ vida son no sólo inseparables, a la vez, la primera es fuente de la segunda. Es decir, la vida no termina con la muerte; más bien con la muerte comienza la vida. Como bien anota Juan van Kessel: "el ciclo de la vida no es la existencia humana individual que comienza, florece $y$ desaparece, sino la nueva vida que procede de la muerte» ${ }^{2}$. Esto implica que la belleza no se manifiesta exactamente en uno de esos polos sino, más bien, en la conexión entre ambos, vale decir, en la muerte-vida hay belleza.

También hay que tener en cuenta varios tipos de fallecimientos. Uno es el de 'alma wawa' o 'ángel', donde abunda el gozo. Otro tipo es el de muchos jóvenes $y$ adultos que fallecen trágicamente como producto de enfermedades $y$ accidentes enmarcados por el empobrecimiento y la carencia de derechos a la vida. Otra clase es la muerte de quienes son considerados

2 Juan van Kessel, aRitual mortuorion, en Cuando ande $d$ tiempo sagrado. La Paz: HSBOL, 1992, p. 98. 


\section{DIEGO IRARRAZAVAL}

'condenados' y no descansan a causa de sus faltas graves a los códigos andinos. Otro tipo es el de personas mayores que mueren-viven plenamente, $y$ con las que se expresan mayores atenciones artísticas. $\mathrm{Mi}$ reflexión se refiere a estas últimas. No consigno actividades $y$ ritos (son millares $y$ son complejísimos); más bien, considero sus elementos artísticos $^{3}$. Voy a considerar seis rubros: alimentación y música (dos constantes en todo el ciclo) y los cuatro momentos del ciclo: fallecimiento, velorio, entierro, fiesta de almas.

\section{a. Alimentación}

Las familias y comunidades andinas (sobre todo aquellas con mayor dignidad tradicional) alimentan ceremoniosamente a las 'almas' $y$ a sus acompañantes. El arte de cocinar con ingredientes andinos $y$ sus sabores se combina con el cariño religioso hacia los difuntos. Los alimentos, bien preparados y respetuosamente servidos, son los que el 'alma' más disfrutaba en su vida y que más agradece en su nueva existencia. Es muy hermoso como disponen estas ofrendas en el altar familiar (el primero de noviembre), en la tumba o panteón (dos de noviembre), y

3 Material etnográfico: José María Arguedas, La muerte y los funeralesw en Señores $e$ indios: acenca de la cultura quechua, Buenos Aires: Callicanto, 1976, pp. 147-150; J. van Kessel, art. citado; Luis lbérico M., ala muerte en el folklore de Cajamarcas, Revista de la UN.T. de Cajamarca, 1974, 49-74; R. Valderrama y C. Escalante, Apu Qorpunas, Debates en Antropología, 5 (1980), 233-264; Víctor Ochoa, boletines ocasionales Nros. 12, 27, 39, IDEA, Puno; W. Carter y M. Mamani, Irpa Chica la Paz: Juventud, 1982, 329.369. He obtenido muchos datos de estos escritos. También agradezco los aportes dados por Santiago Mendora y Juan Mallea, del equipo de IDEA, Puno. 
durante los tres primeros aniversarios del fallecimiento. También es bello el rito del compartir entre los acompañantes: en el velorio una sopa y mates calientes de hierbas $y$ alcohol, en el entierro una sopa $y$ un 'segundo' de 'phatasqa' (cebada, papas, carne de cordero y llama) y en Todos los Santos un 't'impu' de papas, chuño, arroz, y carne de cordero. Todos reciben su porción y la consumen minuciosamente $y$ en silencio. Se sacia el hambre $y$ se consolida la comunión entre todos.

Esta comunión afectiva, sensual y espiritual es fortalecida por la bebida alcohólica y la coca. Cada uno pasa al prójimo el vaso y la botella, le saluda ceremoniosamente y satisface la sed de muerte-vida. También se abre la chuspa de coca para chacchar con el prójimo y sentir juntos el tránsito de la oscuridad a la luz. Al respecto, un observador externo puede quejarse por el exceso de alcohol y los comportamientos irracionales de los ebrios, pero quienes participan en dicha comunión ritual desarrollan su lógica del encuentro y el éxtasis.

\section{b. Música}

A la familia y a las amistades del 'alma' se les ofrecen pocas y cálidas palabras de condolencias, con un tono de voz muy especial. Es una música verbal, con un tono de lamento, de intimidad y de asombro ante el misterio de la muerte. A veces también es un tono de reconciliación, en el caso de personas con quienes se ha vivido conflictos. Estas melodías verbales también caracterizan los 'responsos' hechos por rezadores, líderes autóctonos, catequistas católicos, pastores evangélicos. Las palabras estereotipadas y a veces inentendibles, con términos doctrinales y bíblicos, no importan tanto; lo que llega 


\section{DIEGO IRARRAZAVAL}

al corazón es el tono musical del 'responso': solidario, sensible, triste, esperanzador. A veces, hay canto ${ }^{4}$.

Otra melodía muy honda es el llanto ritual. En torno al fallecimiento, durante el velorio, al salir con el cadáver de su hogar, en el cementerio y al ponerlo en la tumba, algunas mujeres hacen un coro de lamentos, de despedida calurosa, de protesta ante el dolor, de fe. Como anota Arguedas: «la voz aguda de las mujeres (es) como una llamarada que alcanza la cumbre helada de las montañas y envuelve el cielo, las llanuras y los ríos. Nada del horizonte queda sin que le haya tocado la esencia mortal de este coros 5 . Es un canto cósmico para una muerte que afecta todo.

En muchos lugares, principalmente aymaras, el entierro es realizado con un conjunto de zampoñas $y$ bombo, o bien con una banda de músicos. El sonido agudo y penetrante de las zampoñas, y el compás golpeado por el bombo, hace a todos sentir y compartir el dolor. Son pocas y pausadas las melodías características de los funerales, que entran por los oídos hasta el alma de todos los presentes. Cuando hay violines es

4 Un canto preferido en algunas zonas andinas (a veces dirigido a las almas, otras veces a las ánimas y también al Espíritu Santo) es:

Almaykuman hamuy

Espíritu Santo

ghapaq graciaykiwan

k'ancharimuwayku.

Waqchakunapa Yayan

qhapaq qokurniyoq

sonqoyku kallpanchaq

Ilump'aqlla kawsachiq.»

5 Ver, por ejemplo, Vientos del pueblo: poesía, cuento testimonio y pintura, Lima: CIED, 1983 (es un concurso artístico popular); Imágenes y realidad, Lima, 1990 (concurso anual de dibujo y pintura campesina animado por ONG's en todo el Perú). 
ARTE DE MUERTE Y VIDA

mayor el estremecimiento y la congoja. Esta música es también un arte que convoca y une a todos.

\section{c. Moribundo y familiares}

El periodo antes de la muerte suele ser desgarrador debido a enfermedades aplastantes, pérdida de comunicación, desgaste en la paciencia de los familiares, pobreza que impide atender bien al moribundo. Algunos lo viven con tranquilidad y desean la muerte $y$ su descanso. En medio de todo esto hay acciones que manifiestan amor y belleza. Resaltan las instrucciones dadas por el moribundo a su familia con respecto a bienes materiales, consejos para vivir bien, modos de resolver problemas. Sobre todo, resalta el gesto de perdón intrafamiliar antes de morir: tiernos abrazos de una muy emocionante reconciliación y confianza mutua. Se trata de gestos bellos porque nacen de la compasión $y$ el cariño.

Otras expresiones con calidad artística son las oraciones rítmicas y melodiosas junto al moribundo; en especial el rezo del rosario y los pedidos para su salvación hechos por los rezadores. Otros gestos cálidos, al ocurrir la defunción, son, por ejemplo, prender velas a los pies 0 al costado del cadáver, poner flores o un crucifijo detrás de su cabeza o en sus manos.

\section{d. Velorio y acompañamiento}

El difunto vive y así es tratado. No se le abandona, siempre tiene sus acompañantes. El velorio es un oasis de fe $y$ de humanidad. (Este fiel acompañamiento, y el rito de perdón ya mencionado, me conmueven mucho; $y$ los comparo con las costumbres de sectores pudientes). 


\section{DIEGO IRARRAZAVAL}

Es conmovedora la atención al difunto-viviente. El respeto $y$ arte al lavar su cuerpo, con agua de retama y de palmas (del Domingo de Ramos). El vestirlo con ropa de fiesta y ponerle buenos zapatos ( $y$ "así será respetado en la otra vida»). El ponerlo suavemente sobre una mesa con su poncho negro y los pies hacia el Oriente (hacia la salida del sol, hacia el comienzo de la vida). Y, finalmente, con el cadáver se hace un altar: la mesa, mantel negro, flores, velas, crucifijo, agua bendita, en torno al cuerpo-alma. Este altar se levanta en la mejor habitación del hogar, donde, pegadas a los muros, se colocan las bancas para las personas acompañantes. Hay un orden agradable.

También es notable la interacción entre difuntofamiliares-acompañantes. Es un arte del diálogo y la solidaridad. Cada persona que entra al velorio le reza al difunto: Padre Nuestro en silencio, y a veces el Ave María, Gloria, Credo. Algunos le piden perdón. Algunos lo abrazan, abriendo las manos y brazos en torno al cajón. Con una flor se le bendice rociando el agua que hay en un recipiente a los pies del difunto. Esta hermosa liturgia continúa con el saludo ritual a los familiares y amistades; un abrazo tocando suavemente los hombros; unas palabras de condolencia y deseo de que el alma se salve; un silencio cálido; unas lágrimas compartidas. Toda esta interacción requiere de un color propio: el negro. Todos los participantes están unidos en el sentimiento $y$ por eso se visten de negro.

Parte importante del velorio es la alimentación (usualmente una sopa y mates calientes, y bastante cerveza y alcohol) y la conversación sobre todo tipo de asuntos incluyendo la vida buena, regular o mala del difunto. El alimento y la bebida, y también chacchar coca, son medios de comunión. (En algunas ocasiones hay incidentes desagradables, facilitados por la abundante bebida alcohólica). En términos generales, el velorio 


\section{ARTE DE MUERTE Y VIDA}

es un armonioso movimiento de solidaridad en el que todos son protagonistas del comienzo de una vida nueva del 'alma' y sus acompañantes.

\section{e. Entierro comunal}

Este 'rito de paso' es un acontecimiento complejo, con muchos símbolos entre todos sus participantes. Con el entierro y la despedida ocho días después, el 'alma' inicia una nueva existencia $y$ sus familiares $y$ conocidos dejan sus penas y también comienzan una vida nueva. Aquí sólo subrayo la sensibilidad andina al celebrar la armonía entre seres vivientes $y$, a la vez, separar tajantemente al difunto de los sobrevivientes.

En el cajón y en la tumba hay hermosos signos de una nueva realidad. Una costumbre tradicional ha sido poner al interior del cajón elementos de uso diario: miniaturas de instrumentos de trabajo -unos para el varón y otros para la mujer-, alimentos, escobitas 'para barrer el cielo'; pero esta costumbre pocos la cumplen hoy en día. Muchos ponen huevos en el cajón (para acabar con las deudas que tuvo el difunto), frutas $y$ panes (para que pueda comer en su viaje a la otra vida). En la tumba se coloca, sobre la cruz, con mucha reverencia una (o varias) corona; símbolo circular que es un complemento al símbolo recto de la cruz. La corona fabricada artesanalmente con el ciprés o el pino verde va adornada con flores naturales de varios colores. (Algunos obtienen del mercado coronas de papel o metálicas). Los colores, en especial el verde, indican vida. Además, tanto la tumba como la ubicación del cadáver en el cajón están dirigidos hacia el Oriente, ya que el alma amanece a una nueva existencia.

Una serie de expresiones de separación y distanciamiento (entre los vivos y el difunto-vivo) son expresiones veraces y bellas. Muestran la verdad de un 


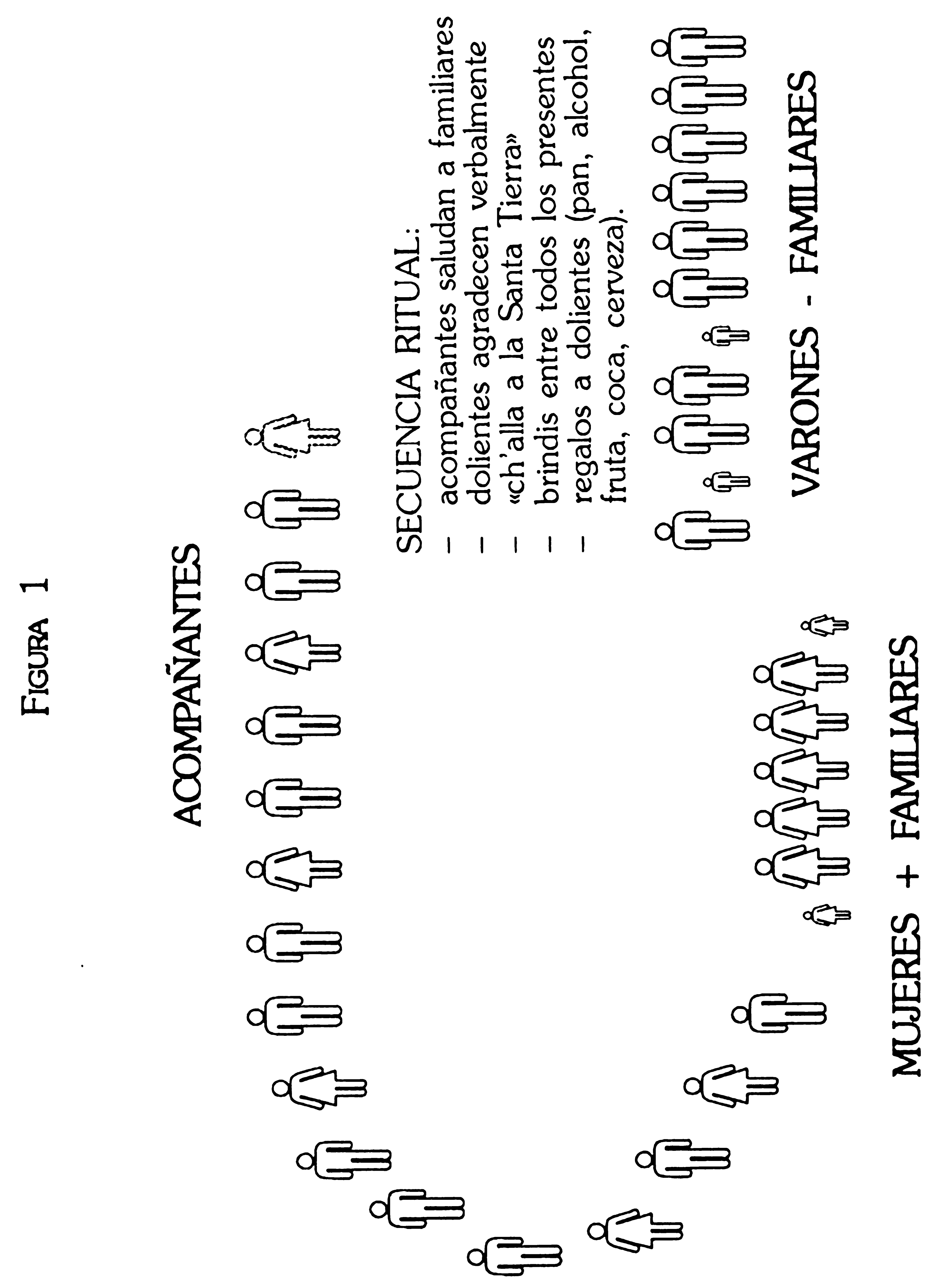


corte y nuevo comienzo y la belleza de nuevas relaciones. El llanto agudo y estremecedor al momento del entierro. A veces unas palabras de despedida. Ofrendas sobre el cajón y dentro de la tumba; puñados de tierra, flores $y$ algodones que los acompañantes se pasan por el rostro y el cuerpo $y$ dan al difunto para que lleve las enfermedades y tristezas. Sacudir con fuerza los ponchos $y$ ropas $y$ hacerles un buen sahumerio de salvia para que se vayan las maldades y penas. Lavar las ropas del difunto. En todo esto se trata de "llaki picharasiñas (limpiar la tristeza), botar los males, acabar con la pena y distanciarse del alma difunta. Después del entierro, se indica asimismo volver al hogar por un camino distinto, para que no regresen las tristezas al hogar, y para poder reiniciar la vida.

Acabado el entierro se hace el saludo ritual: solemne, hermoso, cohesionador, conmovedor. Se hace un círculo de reciprocidad, tal como se indica en la figura 1.

Este círculo de cohesión comunal contiene los principales símbolos andinos de muerte-vida. Según su lógica, la mujer siempre está a la izquierda y los varones a la derecha. Aquí se expresa también la reciprocidad de recibir y dar entre todos los seres vivientes del cosmos; $y$ en cada detalle la armonía reconstruida colectivamente.

\section{f. Fiesta con las almas}

La estética básica de cualquier celebración andina también está presente en la memoria y culto de las almas. La música y danza al 'botar el luto', con ritmos y coreografía del huayno. El arte culinario al invitar alimentos y bebidas, en la celebración de seis meses, un año, dos y tres años. La amistad, acogida y reciprocidad festiva. Las ofrendas y oraciones. 


\section{DIEGO IRARRAZAVAL}

Pongo acento en la celebración del uno y dos de noviembre, ya que es universal. Toda la población andina está de uno $u$ otro modo co-produciendo su arte de muerte-vida. Es el almakunaq p'unchayni (quechua), almanakan urupa (aymara), es decir, el día de las almas.

En primer plano tenemos el arte alimentario.Se trata de regalar con mucho cariño a las almas que regresan a su tierra: se les sirve y ellas disfrutan de lo que más les agradaba y que ahora necesitan para su nueva existencia. El altar familiar, 'tómbola', en la sala principal del hogar, es un bello centro de festividad. Allí se colocan mantos negros, platos desbordantes con sabrosos alimentos, t'anta wawas (panes con representaciones humanas y de animales), maná y frutas, bebidas alcohólicas y no alcohólicas, y también un crucifijo y a veces, la foto del 'alma'. Todo esto dispuesto con simetría y armonía en la mesa-altar. A la vez, se trata de ofrecer alimentos, principalmente galletas $\circ$ bizcochos, a cada visitante que viene a estar con el alma y sus acompañantes $y$, por supuesto, también las bebidas que fortalecen vínculos sagrados entre los seres vivientes. Por otra parte, tenemos las oraciones, hechas por cada persona (como en el velorio) y por especialistas 0 rezadores. Aquí, más que las palabras, importa el gesto cálido de diálogo con el alma visitante. Todo esto es acompañado por el clásico saludo de buena hora, que es un bello movimiento de comunión.

Al recapitular esta sección reitero la clave de lectura: el paso de la muerte a la vida (la dialéctica entre ambas) es expresado con belleza. Cada factor: colores, movimientos corporales, ofrendas, compartir de alimentos, llanto musical, hermosos gestos de saludo y de compasión, etc., cada uno y todos estos factores cultivan una sensibilidad, un arte. Me parece que es un arte común y cotidiano, protagonizado por 
toda la población andina, con sus códigos y valores estéticos frutos de una larga tradición y de una constante recreación e innovación. También resalta la riqueza y complejidad de los símbolos. Lo verbal es sólo un elemento. Podemos decir que se trata de un arte holístico, que recrea lo humano, el medio ambiente y lo sagrado.

\section{Canciones de Vida}

Aquí vamos a considerar la creatividad de personas $y$ grupos, con expresiones verbales en torno a la violencia y la paz. Como en la sección anterior, constatamos en principio la belleza en el tránsito entre factores distintos y contrarios. Aquí, sin embargo, la discontinuidad es evidente y llega a ser absoluta: la acción violenta es contrapuesta a la pacificación. Esta es pues, otra faceta del arte andino, y sus portavoces tienen rasgos más mestizos y mayores influencias de la racionalidad dominante que suele ser dicotómica.

Revisemos un 'corpus' de cantos; un arte proveniente de una población secularmente postergada, y que ha padecido una horrible década de terror. Paulatinamente van surgiendo formas artísticas. Así ocurre en festivales y concursos de dibujo, canto, danza, teatro, poesía, textiles, que enriquecen el Perú de hoy. En estos eventos se expresa con mucho corazón el sentir de un pueblo violentado. A veces hay poco esfuerzo de elaboración artística, $y$ hay obras más testimoniales y de reclamo social. Cabe, pues, en estos casos dar el paso hacia una mayor imaginación y elaboración en la comunicación. 


\section{DIEGO IRARRAZAVAL}

Examino un festival regional de "canto a la paz y la vida" en el Sur Andino6, en que el arte revela muchas llagas y también trasluce gran esperanza. En esta región $y$ en todo el país va creciendo la sensibilidad a la vida -que es derecho de todos- y la oposición categórica a varios tipos de violencia; también es hora de vencer a la maldad con la belleza -que es vocación de todos.

Las comunidades andinas hacen arte en lo cotidiano: amor, desarraigo, solidaridad y crueldad, gozo y desánimo, en fin, en todo lo que caracteriza la condición humana en esta Madre Tierra. Sólo algunos de estos elementos ingresan en el arte verbal -las canciones-: la vigorosa esperanza, un desvelamiento de la insoportable realidad, una fantástica fe en la vida y la apuesta de pasar de la violencia a la paz. Gran parte de los cantos afirman que, desde la maldad, hay que pasar hacia una vida digna y alegre. Esta intermediación está presente en el arte.

Mi reflexión gira en torno a las canciones en cuanto tales. No las califico como argumentos en un programa social ni en un esfuerzo evangelizador (aunque estas dimensiones también están alli, en los textos). Más bien, desentraño los códigos artísticos. Un pueblo como el andino -con su espíritu tan bello- dice lo que es y lo que desea. Tiene vida y busca mayor vitalidad. Esto contradice tanto atropello y desprecio como el que se ha padecido en estos años de terrorismo y de violencia legal.

6 Ha sido convocado por el Consejo Regional por la Paz y promovido por el CODDEHH-PUNO y las Vicarías de Solidaridad de Ayaviri, Puno y Juli de la Iglesia Católica. En cada zona se realizaron etapas eliminatorias; el evento final fue el 13-12-92. Han participado 24 canciones, con música y letra propias de cada conjunto. Cuando las cito, en este artículo pongo el número según el onden en el que se presentaron el 13-12-92. Los nombres de los grupos y de los temas, así como el onden de presentación, se consignan en el anexo. 


\section{a. Afirmación de esperanza}

El canto quechua y el canto aymara tienen sus ubicaciones. Principalmente se ubican en el ciclo festivo del mundo andino; y allí resaltan el gozo y la esperanza. También hay mucho lamento por el desarraigo, por dolores de amor, por orfandad y por muerte. En el caso de cantos con un sentido socio-político -según el prolijo análisis de los hermanos Montoya- salen a luz estas vertientes: mucha aceptación de la dominación, una constatación de la opresión y algunos cantos expresando rebeldía?. Aunque es escasa la protesta explícita, sí abunda el anhelo de vida más plena (por ejemplo en cantos de carnaval y en otras celebraciones).

Por otro lado, tenemos una industria cultural que difunde falsedades $e$ incoherencias. Su horizonte parece ser una "cultura del éxito", sin ética. Es una industria muy rentable; cautiva a gran parte de la población. Llama a concursar y a obtener fabulosos premios. En caso de perder, la resignación es superada por el sueño de posibilidades que pueden hacerse presente. Es lo que difunden muchos concursos-shows en la televisión («En la mira del éxito», «Fantástico», «Baúl de la felicidad», "Trampolín a la Fama», "Super Lotto", etc.). La felicidad está asociada a dólares y a bienes materiales. Todo depende de la suerte. Las promesas de felicidad están dirigidas a todos, pero muy

7 Rodriga, Edwin y Luis Montoya, La sangre de los cerros, Urqukumapa Yawarnin, Lima: Mosca Azul-CEPES-UNMSM, 1987. Aquú se clasifican los cantos quechuas en 14 tipos: producción, ciclo vital, amor, naturaleza, juego de toros, familia-orfandad, emigración, desarraigo, religión, instrumentos musicales, abigeato y prisión, humor, comunidad, política. En general, el canto es mucho más la expresión de los sentimientos que de una visión social (ver el comentario a esto último en pp. 5458). 


\section{DIEGO IRARRAZAVAL}

pocos la obtienen. Hay pues engaño, incoherencia, fealdad.

Ante estos dos trasfondos (por un lado, la tradición artística andina, y por otro, la alienante industria de la cultura del 'éxito'), ¿qué manifiesta un festival surandino en favor de la paz? Voy a detenerme en los nombres de los conjuntos, los títulos de los cantos y en sus sujetos sociales-artísticos.

Me parecen muy significativos los nombres de los 24 conjuntos. En el universo andino cada tipo de bautizo es transcendental. Poner un nombre a un conjunto de artistas es bautizarlo, darle identidad $y$ significación de lo que se desea en lo profundo del corazón. Lo nuevo define a la mayoría: si es conjunto se autocalifican juventud (y estudiantina), tres se llaman nueva esperanza', y otros tres 'nuevas raíces', 'tierra nueva', 'tiempo nuevo', y dos llevan por nombre 'amanecer'. Tres conjuntos se definen en términos de 'pueblo'; dos llevan el título de 'sangre', uno es 'rebelde' (y hay además otras cuatro denominaciones). Tenemos pues como denominador común el factor de esperanza, y esto es muy bello. El amanecer, las raíces, la juventud, etc. son imágenes de un porvenir mejor.

También es muy significativo el título de cada canción. Abundan las señales de vida renovada: 'paz y vida' (siete cantos), 'vida' (cuatro canciones), 'paz' (cuatro canciones), 'esperanza' (dos cantos), 'justicia' (una canción); dos canciones mencionan a niños $y$ jóvenes, y otras cuatro llevan el nombre del pueblo de origen de los integrantes del conjunto. Es decir, tanto los nombres de los conjuntos, como los títulos de las canciones son signos de esperanza de vida nueva. Esto levanta el ánimo y agudiza la sensibilidad hacia lo bueno y lo bello. Por ejemplo, se dice: «desde nuestro Altiplano unamos todos nuestros cantos por la vida $y$ por la paz» ( $\left.\mathrm{N}^{\circ} 13\right)$; «alegraremos al pueblo.... trabajando 


\section{ARTE DE MUERTE Y VIDA}

y cantando» ( $\left.{ }^{\circ} 4\right)$; «con amor cantaremos dichosos: libertad - y los campos floreceráns ( $\left.\mathrm{N}^{\circ} 10\right)$.

Otro indicador clarísimo de la fuerza de la esperanza es que el pueblo aparece como sujeto de los cantos. Es protagonista de nuevas realidades. En los textos hay más de una docena de menciones de 'todos', de 'hermanos y hermanas', de 'pueblo' (más de una docena de cada una de estas expresiones). Esto se contrapone al repliegue $y$ fraccionamiento que ocurre en situaciones de violencia. También se explicitan, como sujetos, a 'quechuas y aymaras', 'jóvenes y niños', 'amigos y amigas', 'pobres' (cada uno de estos sujetos es mencionado cinco veces). Se habla también de 'gente', 'trabajadores', 'comerciantes', 'campesinos'. En conclusión, la confianza en un cambio sustancial no reside fuera de lo andino ni reside en un caudillo. Más bien, los portadores de la esperanza son 'todos $y$ todas', comunidades y pueblos.

\section{b. El corazón ve la realidad}

Uno de los consensos, en el Perú de hoy, es que hay demasiada desarticulación, miseria y discordia. A partir de una situación desesperante es difícil sumar esfuerzos y construir soluciones. Es más fácil la lamentación (hecha por gente paralizada) o, también, culpar a ciertas personas y grupos por el desastre en que estamos 0 , lo que es lo mismo, encerrarse en una existencia individual $y$ familiar.

En este contexto, se requiere de coraje y de un corazón limpio para ver dónde estamos y a dónde debemos dirigirnos. Es necesario desnudar la fea realidad, y dar pasos decisivos hacia algo agradable. En este sentido, numerosos cantos (en este festival surandino) revelan la maldad, trazan líneas de acción, sacan a la luz las fuerzas en pugna. Parece que sólo un corazón 


\section{DIEGO IRARRAZAVAL}

adolorido $y$, a la vez, bien valiente es capaz de enfrentar la realidad.

La realidad es entendida mediante buenas imágenes: oscuridad y luz ( $\left.\mathrm{N}^{\circ} 1, \mathrm{~N}^{\circ} 23\right)$, «hambreados de paz» (N2), "desamon (N²), «kunaymana ingañatax sarnaktanxa... mayakiwa wali ch'amamp sartañanis (de toda forma engañados hemos andado... unidos con mucha fuerza andemos) ( $\mathrm{N}^{\circ} 3$ ), "clamor de los pobres por la paz» ( $\left.\mathrm{N}^{\circ} 7\right)$, "cantemos hoy, a nuestro pueblo, sus alegrías, sus penas» ( $\left.\mathrm{N}^{\circ} 13\right)$, «la tierra tiembla de dolor por la sangre y hambre de sus hijos, dejen que todos puedan comer con la justicia que Dios nos dio" ( $\left.\mathrm{N}^{\circ} 18\right)$. Cada una de estas imágenes y comparaciones tocan el fondo de nuestra realidad.

También sale a luz la conflictividad humana, expresada mediante binomios: violencia y paz ( $\mathrm{N}^{\circ} 8$, $\left.\mathrm{N}^{\circ} 11, \mathrm{~N}^{\circ} 15, \mathrm{~N}^{\circ} 18, \mathrm{~N}^{\circ} 19\right)$, odio $y$ amor ( $\left.\mathrm{N}^{\circ} 8, \mathrm{~N}^{\circ} 14\right)$, violencia y destrucción - justicia y paz $\left(\mathrm{N}^{\circ} 7\right)$, tristeza y fiesta $\left(\mathrm{N}^{\circ} 4\right)$, miedo y fraternidad $\left(\mathrm{N}^{\circ} 3\right)$, muerte y vida (N23).

Por lo tanto, no se oculta ni se mistifica la dura realidad de violencias. Con los ojos del corazón se ven los hechos desgarradores. No sólo eso. También se plantea, se intuye, se enuncia una alternativa. Es pues un arte, un cantar verídico. Pocas imágenes bastan para señalar una horrible realidad $y$, a la vez, para enunciar rutas hacia la vida.

\section{c. Fidelidad a la vida}

Se trata de una fidelidad en movimiento, que crece en medio de incontables e inmensos hechos negativos. Durante estos años abunda la desconfianza y el desánimo sobre los asuntos públicos. Parece que todo anda mal, de modo irremediable. Es común escuchar a personas que dicen: ho creo en nadie', 'esto no lo 


\section{ARTE DE MUERTE Y VIDA}

resuelve nadie', 'sólo nos queda morir'. Por mi parte, siempre recuerdo a la persona que, en una entrevista periodística, reconoció «no creo en nadie, ni en mi madre». Superar este feo fatalismo es una gran tarea de nuestros tiempos. En las canciones del festival surandino se evidencia una fe; el arte es creyente.

Es la fe en la vida mancomunada: «amigos todos, construyamos nuestro porvenin ( $\left.\mathrm{N}^{\circ} 1\right)$, «janipuniw kitirusa axsarksnatis (nunca a nadie tengamos miedo) (N०3), «unidos luchemos» (N०7), «buscando que haya paz» ( $\left.N^{\circ} 4, N^{\circ} 5, N^{\circ} 8, N^{\circ} 18\right)$, «llegará la paz y la alegría» ( $\left.\mathrm{N}^{\circ} 10\right)$, "caminando se llegará a la alegría» (No10, No12).

Se trata de una fe sin ilusiones, realista $y$ cuestionadora. Toma en cuenta la complejidad del acontecer humano. Hace preguntas que no tienen respuestas. «Me pregunto Dios mío.... ¿por qué será que tantas madres están injusticias guisando?» (N²); «¿por qué Dios tanta corrupción?» (N¹7); «¿por qué Señor tanta violencia?» ( $\left.\mathrm{N}^{\circ} 18\right)$. Se habla con Dios con gran franqueza, y planteando nuestra perplejidad ante la maldad. Con sinceridad se interpela a Dios. La violencia es inaceptable; Dios tiene que traer la paz.

Además, en medio de incertidumbres $y$ angustias, es una fe que conlleva compromiso: «todos juntos haremos la historia» ( $\left.{ }^{\circ} 2, N^{\circ}, N^{\circ} 10\right)$.

"Oh Dios que caminas junto a tu pueblo de tanto sollozar y agonía

tus hijos te claman paz y vida

y están dispuestos a construirla» (N²3).

«Ay Dios mío

Padre de la vida,

eres testigo de la esperanza

eres testigo de nuestro esfuerzo» (N²1). 


\section{DIEGO IRARRAZAVAL}

"Jesussan qhanapan taqin sarapxañani Jesusan thakipan taqin sarapxañani» (en la luz de Jesús todos vamos en el camino de Jesús todos vamos) ( $\left.\mathrm{N}^{\circ} 14\right)$.

«Todos juntos triunfaremos siguiendo el camino de Jesús con nuestra alegría y trabajo» ( $\left.\mathrm{N}^{\circ} 15\right)$.

No se trata pues de una fidelidad rutinaria, estancada, pesimista. Por el contrario, se conjuga la acción humana con la oración a Dios y con la energía comunitaria. El ser humano trabaja por la paz y la busca, y le pide a Dios que es fuente de paz, que así sea ( $\left.\mathrm{N}^{\circ} 12, \mathrm{~N}^{\circ} 15, \mathrm{~N}^{\circ} 23\right)$.

\section{d. Arte y transformación.}

Ya hemos anotado cómo la sensibilidad andina se manifiesta en la esperanza, la verdad, la fe. Todo esto va orientado a la transformación de condiciones de violencia en condiciones de armonía. Esto caracteriza la producción artística. Lo hemos subrayado al hablar del paso entre muerte-vida; ahora lo hacemos en referencia al paso de violencia-paz. El arte, como nos indica Verónica Cereceda, es una mediación entre términos distintos. De la maldad se camina hacia el gozo. De la anomia se pasa al bienestar. Al examinar los cantos uno detecta dos momentos.

El primer momento es un distanciamiento de la maldad. El canto andino siente hondamente el dolor, denuncia e impugna la maldad. "Penas que agotan.... entre enredos y trabajos" ( $\left.\mathrm{N}^{\circ} 4\right)$. "La destrucción y la violencia se suenan en todas partes» ( $\left.\mathrm{N}^{\circ} 7\right)$. "No hay justicia, sólo existe mucho sufrimiento» ( $\left.\mathrm{N}^{\circ} 9\right)$. «Lágrimas, odio, y rencor de tanta violencia» $\left(\mathrm{N}^{\circ} 11\right)$. «Nos unire- 
mos para vencerlo» ( $\mathrm{N}^{\circ} \mathrm{9}$ ). En general, la denuncia hace referencia al hambre, pavor, marginación, desprecio, corrupción, matanza, tormento, tortura. A estas palabras que expresa una oposición a la maldad se suman unas invocaciones conmovedoras:

«janipuniw qhiti sallkarus

«janipuniw qhiti c'arirus

jiwasanacaxa iyausapcsnati»

(nunca a alguien maligno

nunca a alguien mentiroso

nosotros aceptemos) ( $\mathrm{N}^{\circ} 3$ ).

«jiwasanackamakiw uñisisiptanja

janiw unasiñasaj utjquistuti

janiw mayaru tucuñ puedipxtanti

jan ucasti jach'a jach'a cancañaj»

lentre nosotros nos odiamos

$y$ no nos queremos

no podemos unirnos

todos aparentamos ser grandes) ( $\left.N^{\circ} 14\right)$.

Tomar pues distanciamiento de la maldad es como una primera manifestación del movimiento hacia la paz. El arte da testimonio de este movimiento.

El segundo momento, que es un denominador común en muchos de los cantos que estamos examinando, es un nítido clamor por la vida. Hay muchas imágenes de la transformación de la existencia humana: caminar unidos ( $\mathrm{N}^{\circ} 3, \mathrm{~N}^{\circ} 10, \mathrm{~N}^{\circ} 11, \mathrm{~N}^{\circ} 18, \mathrm{~N}^{\circ} 23$ ), luchar, lograr justicia y libertad ( $\mathrm{N}^{\circ} 2, \mathrm{~N}^{\circ} 5, \mathrm{~N}^{\circ} 7, \mathrm{~N}^{\circ}$, $\left.\mathrm{N}^{\circ} 16, \mathrm{~N}^{\circ} 19, \mathrm{~N}^{\circ} 21\right)$, sembrar y construir la paz ( $\mathrm{N}^{\circ} 10$, $\mathrm{N}^{\circ} 13, \mathrm{~N}^{\circ} 14, \mathrm{~N}^{\circ} 15, \mathrm{~N}^{\circ} 17, \mathrm{~N}^{\circ} 18, \mathrm{~N}^{\circ} 22, \mathrm{~N}^{\circ} 23$ ), «que el hambre, muertes injustas, tengan que acabar ahora» ( $\left.{ }^{\circ} 24\right)$, «llaktanchis sonqonmanta pacha, panaykuna qankunawun quska, kausaypak kausaynintan, phuturichisunchis Peru llaqtanchispin (desde el corazón de mi 


\section{DIEGO IRARRAZAVAL}

pueblo junto con uds. haremos brotar dentro de nuestro pueblo peruano la paz y la vida) ( $\left.{ }^{2} 20\right)$.

En la sensibilidad artística, estos dos momentos, se vuelcan hacia la alegría. Es decir, tanto la maldad como el afán por la vida, al interactuar entre ellos, son transformados y pasan al plan superior de una alegre paz.

«Cantemos felices
cantemos alegres
por la paz y el amor,
es el canto más querido
por la liberación» (N6).

«Todos juntos triunfaremos siguiendo el camino del Señor con nuestra alegría y trabajo, que viva Cuyo Cuyo, Sandia, que viva nuestra tierra Perú» ( $\left.\mathrm{N}^{\circ} 15\right)$.

«Llenos de esperanza, de amor y de fe, constructores de nueva humanidad, somos el pueblo, somos la paz, somos la vida y el amons (N20).

"Ven conmigo, vamos juntos... hagamos florecer paz y vida...» (N23).

Por consiguiente, en este arte la meta no es la congoja ni la incertidumbre. La vida vale, y por eso es transformada. De la maldad de la violencia se transita hacia la paz. Este tránsito es bello, es gozoso.

La música da mucho sentido a estos textos y a sus cuatro líneas de fondo que he examinado: esperan$\mathrm{za}$, fidelidad a la vida, ver la realidad, arte y transformación. La significación de los textos es inseparable de las melodías con que se expresan. Por ejemplo, los 


\section{ARTE DE MUERTE Y VIDA}

vibrantes sonidos de la zampoña y la quena hacen sentir el afán radical por la vida. Las melodías de charangos, mandolinas, chilladores, guitarras, hacen bailar el corazón de alegría. El golpe rotundo de bombos y tambores nos abren al misterio que no tiene definición, pero que es nuestra morada. Cabe reconocer que es más clara la melodía de una quena que una consigna concientizadora. Lo reitero: los textos son significativos, sobre todo, por la música que los fundamenta.

También cabe ofrecer una crítica. Estos cantos contra la violencia y a favor de una vida nueva tienen calidad como arte. Pero también abunda un lenguaje reivindicativo y conceptual que no corresponde a una obra artística. Esta problemática la encontramos también en otros eventos. Por ejemplo, al comentar unos dibujos sobre la violencia, Juan Ansión dice que dichos dibujos son «los menos trabajados estéticamente», como si «una tragedia tan grande no permitiera la tranquilidad del alma necesaria en la búsqueda de la belleza» ${ }^{8}$. Uno desearía que los artistas vayan más allá de lo conceptual y lo ético. En la paciente elaboración artística se llega a un nivel de sensibilidad y de verdad. Sus imágenes tocan el corazón y lo transforman.

En conclusión, en la producción artística andina -como en todo su modo de ser y su cosmovisión- constatamos un movimiento entre elementos distintos. Al examinar las costumbres en torno al fallecimiento $y$ el 'alma', resalta la reciprocidad entre muerte-vida; y el movimiento entre ambas es sumamente hermoso. Al considerar

1990 , p. 24.

8 Juan Ansión, su introducción a Imágenes y Realidad, Lima, 


\section{DIEGO IRARRAZAVAL}

las canciones de un festival surandino, los polos de la violencia y la pacificación tienen sus mediaciones: la esperanza y la fe en la vida. En este movimiento también hay belleza. Por lo tanto, el arte andino no es sólo una obra que se admira y disfruta; no es sólo una recreación de la realidad cotidiana que toca nuestros sentimientos más profundos. Evidentemente, ella es todo lo que se acaba de anotar. Pero aquí se ha subrayado otro rasgo de la creación artística: la belleza en el movimiento entre vida-muerte $y$ entre violencia-paz.

Ahora bien, el arte expresa sensibilidades en el presente y también la humanización del porvenir. Ante la mundialización de un tipo de éxito material, la belleza de la muerte-vida andina es una de las señales hacia una nueva condición humana. Con respecto a la resignación moderna ante estructuras de violencia, el arte andino como todo quehacer artístico abre rutas de esperanza y de fidelidad a la vida.

También subrayo la mayor riqueza simbólica y calidad artística en la producción de la gente común. Así lo demuestran sus expresiones en torno a la muerte-vida. Las obras hechas por especialistas (en este caso: cantos escritos por jóvenes estudiantes, profesionales, agentes pastorales, etc.) suelen ser una comunicación directa y menos elaborada artísticamente. Por eso, son importantísimos los contactos entre todos los sujetos andinos $y$, en especial, que los artistas profesionales beban y se alimenten de tanta creatividad artística de la población andina. 


\section{Anexo}

\section{Canciones y Temas de Festival \\ Regional de Canto a la Paz y la Vida}

1. Grupo «Lluvias del amanecer (Crucero); tema: 'Decídete juventud'.

2. Conjunto 'Estudiantina 861' (Ayaviri); tema: 'Plegaria para los niños'.

3. Grupo 'Sanka-ira' (Yunguyo); tema: 'Suma jacañat arsuri'.

4. Conjuntos 'Los Claveles de quiaca ayllu' (Sandia); tema: 'Esperanzas en la vida'.

5. Grupo 'Tiempo Nuevo' (Huancané); tema: 'Canta el hombre a la paz y vida'.

6. Grupo 'K'anamarca' (Huancané); tema: 'Buscando la vida y la libertad'.

7. Conjunto 'Juventud Tierra Prócer' (Azángaro); tema: 'Los pobres por la vida y la paz'.

8. Grupo 'Nueva Generación Franciscana' (Juliaca); tema: 'Cantemos por la paz'.

9. Grupo 'Nuevos rebeldes de Sicuyani' (Zepita); tema: 'La Justicia'.

10. Grupo 'Tierra Nueva' (Ayaviri); tema: 'La paz en América Latina'.

11. Grupo 'Illary' (Ayaviri); tema: 'Camino a la esperanza'.

12. Conjunto 'Familia Aguilar Yupanqui' (Huancané); tema: 'Paz para el mundo'.

13. Grupo 'Taki Marca' (Juliaca); tema: 'Paz y Vida'.

14. Conjunto 'Nueva esperanza del 15 de agosto' (Zepita); tema: 'Suma jacaña'.

15. Grupo 'Sicuris del movimiento juvenil de Cuyo Cuyo' (Sandia); tema: 'Paz y Vida'. 


\section{DIEGO IRARRAZAVAL}

16. Grupo 'Nuevas Raíces' (Coaza); tema: 'Coazeño Coaza tierra querida'.

17. Conjunto 'Estudiantina Juventud los Bohemios de Ñuñoa' (Ñuñoa); tema: 'Buscando la paz'.

18. Grupo 'jakañ wila' (Juli); tema: 'Por una vida mejor'.

19. Conjunto 'Estudiantina Nueva Esperanza de Collini' (Acora); tema: 'Recuerdos de Collini -paz y vida'.

20. Grupo 'Ricchary Huayna' (Sandia); tema: 'El anhelo de mi vida'.

21. Conjunto 'Nor-este de Juliaca' (Juliaca); tema: 'Qué tiene mi pueblo'.

22. Grupo 'Sankayos' (Azángaro); tema: 'Pueblo por la vida y la paz'.

23. Conjunto 'Juventud nueva esperanza de Crucero' (Crucero); tema: 'Construyamos vida y paz'.

24. Conjunto 'Yawar Amaru' (Azángaro); tema: 'Canto a la vida y la paz'.

El No 22 obtuvo el primer premio en la categoría 'Grupos de Folklore Andino'; y el $\mathrm{N}^{\circ} 23$ el primer premio en la categoría 'Conjuntos de Cuerda'. 